\title{
Public Burial Place for Believers of God as Fulfillment of Welfare State in Indonesia
}

\author{
Tuti Widyaningrum \\ \{tuti.widyaningrum@gmail.com $\}$
}

Universitas 17 Agustus 1945 Jakarta, Jakarta, Indonesia

\begin{abstract}
Regulation of Public Burial Place in Indonesia was regulated by Government Regulation (PP) No.9 year 1987 about Land Use Provision for Public Burial Place. According Article 4 Number 2 PP No.9 Year 1987 stipulated, for public order and neatness of public burial and non-public burial was providing site for each religions. This regulation was closed opportunity of believers to enjoy their rights to have public burial place, so in many region in the burial of believers of God was rejected because they were not a religionist. After decision of Constitutional Court that make sameness among belief and religion, so it's time to accommodate burial of believers in public burial place. This research using juridical normative method with conceptual approach from sociology of law to became solution of research questions.
\end{abstract}

Keywords: Public Burial Place (TPU), Believers of God, Human Rights

\section{Introduction}

One of kind of Human Rights for the last time in human life is proper buried according with their religion and belief. Naturally people who passed away should be buried in some place or some way depend on their tenet and conditions of their social life. But not everyone especially in Indonesia could enjoy proper buried as were like believers of God. The believers of God had special treatment/activity or different way to make proper buried rather than religionist. In Indonesia, believers of God still facing harassment and discrimination related their conscience because the society still as sume the believers of God is not a religionist, so in many cases theircannot buried people in public burial place. In many regions in Indonesia, their faced rejection from majority religion because the basic reason of refusing is concern about their faith. The majority religion as sume buried of believers in public burial place will broke up the order of community. So it impact, believers of God can not buried their family as proper buried like the other. Beside that theoretically they cannot enjoyed their rights as citizen as like a kind of fulfillment of their human rights.

In funeral terminology, it's explain with an activity buried body or corpse in burial place. The body of the people whose medical declared has passed away should be buried in public burial place (TPU), where that place that used to be funeral activity is owned and managed by the government. The burial site is the land of area that should provide and or be used to burial the body with special measurement. On the other hand, a simply terminology about the cemetery, there were the formof the cemetery like s pare tomb, mix grave or family cemetery. A cemetery is defined that some place where the body buried, and then spare tomb is mean that the land area of cemetery that have been reserved and spare for burial at a later time. Furthermore mix grave is defined that cemetery area that use fortwo body or more within the family. [1].

The Government had responsibility to provide public burial place, particularly in local government. Regulation of Public Burial Place in Indonesia was regulated by Government 
Regulation (PP) No.9year 1987 about Land Use Provision for Public Burial Place. According Article 4 Number 2 PP No.9 Year 1987 stipulated, for public order and neatness of public burial and non-public burial was providing site for each religions.[2].

Public burial place is supposed to intend for all people citizen of Indonesia without seeing their religion or faith/belief. But in fact Public burial place was dominated and as though owned by people from majority religion. When believers of God passed away they cannot buried their family freely like the other religions. The Believers of God have bad experience through rejection for buried in public burial place from majority religion (Is lam). The believers of God still facing discrimination through their faith because they not categorized from any religion that registered in Indonesia.

There so many cases of rejection for burial of believers of God in Indonesia, like burial rejection in Brebes and Indramayu regency is real happened for example of discrimination against believer in God because their different faith than the religions. The rejections of believers of God like Sapta Darma also occurred in Cikandang Village Sub-dis trict of Kersana in Brebes Regency in year 2010. In that place, the society rejected buried of women believers of Sapta Darma in local public burialplace. The impact of rejection is forced them to buried their family on their backyard of home. As same as in Kers ana, in Wanasari Brebes regency, the believers of Sapta Darma in 2007 and 2012 had faced same incident. For anticipating the incident, local government asking for believers of Sapta Darma to provide burial place for themself, that cannot put together with burial place of Mos lemcemetery. Meanwhile the same incident take place in Sikancil village sub-district of Larangan Brebes Regency in 2011. In this place, where there is a tomb of believers of Sapta Darma was broken and demolished because the tomb is located in public burial place. The demolishing of the tomb of believers has been done with local people whose do not want to there were a body of believers of God lay down in Moslem cemetery.[3].

The problem of discrimination aboutfreedom of conscience and faith against believers of God in Indonesia was occurred massively. The greatest barrier of believers of God is still facing of Law Number 1 PNPS year 1965 about Prevention, Abuse and/or blasphemy of Religion. This law made separation between religions and believers of God. This law ruled freedomof religions, about faith which allowed and not allowed, having house prayer, and also practicing rituals. Finally this law hang up believers of God and decided that believers is deviate so cannot spread out and develop and also tend to prohibited. The lack of state protection make believers of God had difficulties to enjoy and manifestation their faith. The believers of God still difficult to build house of prayer and prohibited doing rituals until not allow to buried people in their living ground. [4]

For those problem the Government had try to manage it as their responsibility for believers of God as same as citizen of Indonesia. In Join Rules (PBM) of Mendagri and Mendikbudpar about The Guidance of Service to Believers of God Number 43/41 Year 2009, stipulated in Articles 2 about the service scope that given from local government it's comprise administrations of believers organizations and other service to making capacity building of organization such as meeting hall and burial service. Related with burial service for believers of God, stipulated in Article 8 point 1, the buried of believers of God were place in public burial place, and then point 2 said "if burial of believers of God rejected from public burial place which came from waqafland, so Local Government should provide public burial place, but contrary in point 3 , if there were in public burial place facing rejection, believers of God should provide itself to make some burial place.

Despite of that the less of socialization and still strength of resistance from society against believers, make that rule is only like an accessories that cannot be implemented in 
every regions. Meanwhile in democratic state, government should respect and honor with all human rights again st their citizen including believers of God. The protection of human rights is still necessary to guarantee fulfillment of public welfare real happened for all pe ople without discrimination. According that case researcher want to research about how the concept burial rules against believers of God as fulfillment of welfare state in Indonesia.

This study aims to encourage social change through law awareness and law making to create equal treatment for proper buried for believers of God in public burial place. Beside that respects and honor of human rights in public burial place for believers of God reflected equality treatment as same as citizen of Indonesia can be seen as the fulfillment of welfare state concept in Indonesia.

\section{Method}

This research using juridical normative method or normative legal research approach by doing an abstraction of the process of deduction from the prevailing positive legal norms, namely examining the law as a positive normusing deductive thinking and based on coherent truth, where the truth in this study has been declared credible without having to go through a testing or verification. This research using secondary data and analyze with conceptual approach from sociology of law to became solution of research questions. Sociology of law became the key to open mind that the problem of public burial place for believers of God is part of community life.

\section{Result and Dis cussion}

According Government Regulation (PP) No.9 year 1987 about Land Use Provision for Public Burial Place, there is define categorical about public burial place, non-public burial place and special burial place. The public burialplace as stipulated in article 1 PP No.9 year 1987 about Land Use Provision for Public Burial Place, is defined as land area that intended for burial of body for every people without dis tinguis hing religion or groups, that managed by Government of Regency or government of villages. The explanation of that regulation is mentioned that for all unidentified bodies or unidentified their religion, the burial process take place in particular place on that public burial place.

Meanwhile about non-public burial place is land area that provide for buried body that managed by social organization and or religion organization. Related with this non -public burial place, the role of government is giving permit that accelerated with regional development plan and surrounding order. Furthermore the special burial place is land area which used to be burial place because it have historical as pect and or have special cultural as pect that have peculiar meaning for their owned. Beside that there were a crematorium that intended for cremate body which managed by local government, community or social and or religion organizations with considering conditions of local government and mortuary.

Related with fulfillment of the citizen rights whose became constitutional rights belong to believers of God, should deeply thinking about rights and human rights also citizen rights inside of. The matter to be note that where the right to individual freedom is a result deduced from the principles of the constitution, the idea readily occurs that the right is capable of being sus pended or taken away. Where, on the other hand, the right to individual freedom is part of the constitution because it is inherent in the ordinary law of the land, the right is one which can hardly be destroyed without a thorough revolution in the institutions and manners of the nation.[5]. 
The Welfare state concept was guaranteed Constitutional rights for every people related to fulfillment of their human rights to increase quality of human being. The aim of welfare state is giving public prosperity to all people. No matter thing in welfare state except giving public welfare. The aims of people prosperity show us that the rule of law have orientation to public interest so it's called populis.[6].

Despite of that the orientation of welfare state cannot perfectly happen when faced about discriminations against burial of believers of God. Even if there is Constitutional Court Decision Number 97/PUU-XIV/2016 about judicial review of citizen administration that decide those word of "agama" has no legally binding when not including believers of God. But even those change in Citizen Administration Law not enough equal with rising of protection to freedom of conscience for believers of God. When freedom of identity of believers of God should be registered but the problem of conscience including manife station of their faith cannot freely to do including their burial rites.

The purpose of the law is as a tool for social change so that if the law can be implemented properly the purpose of the law can bring happiness to as many people as possible. Lawrence M. Friedman said that to realize legal certainty must regard the legal substance, legal structure, legal culture and legal impact. [7]. The law in its construction is motivated by the principle of law which is the basic thought in the formation of laws and regulation, the principle of law is the basic thought behind the construction of concrete legal regulations as stated in the legislation thoughts.

The rule of public burial place in PP No.9 Year 1987 has been long existed for 5 religions in Indonesia. This condition has affecting implementation of service for believers of God. Although it had been socialized from Kemdikbud from 2009, but until now, these regulation not effective to change ag ainst discriminations because the structure, substance and culture of society still neglecting and refusing believers of God as part as "agama". Furthermore the service of burial of believers of God was collide with what whom or which group believers that had been registered in Kemdikbud.

According Jimly As sidiqie, inside of Rechtstaat is defined that there were recognition of supremacy of law and constitution, separation of power based on constitutional system that ruled by UUD 1945, guarantee of human rights, independent and fair trial that guaranteed of equality before the law and also guaranteed jus tice for every people including for power abuse from government.[8] Thereforeit's need Government interventions to fulfilling burial rights for believers of God as like other citizen. If the rule was made not support fulfilling the aims of welfare state or not giving some advantages for every people that mean there's a problem from wrong procedure. Friedman said that the procedure just one of the way to reach the aims, but the aims is those problemwhose attack by anything by the peole. The procedure follow substance and the substance that told us what the matter from that procedure could be importance.[9]. So when we meet the bigger advantage things become substance that should be reach, it's not a big problem when we change or erase the bad procedure.

As long as the rule of Law Number PNPS 1965 about Prevention, Abuse and/or blas phemy of Religion still open chance to disband of believers of God organization and or prohibiting believers of God to practice their belief, undoubtedly the protection of freedom of cons cience in God like the other religion is not make it happened. On the other words however there are ruled about the burial service for believers, it's worst thing when their community not registered and recognized by the state. As a matter of course when the state want to fulfilling the rights of believers of God, the government must implementing Constitution Court Decision Number 97/PUU-XIV/2016 about judicial review of citizen adminis tration law, and then the government must revoke all operational regulation that obstruct the 
fulfillment of the rights of citizen and human rights of believers of God. Furthermore it needs to revoke and change it into government regulations that more accommodate the interest of all religions and believers of God in Indonesia. With changing all procedure which obstruct fulfillment of constitutional rights of believers of God related the freedom of belief and conscience it will make reflections of welfare state which is advantage for all people of Indonesia.

PBM of Mendagri and Mendikbudpar Number 43/41 Year 2009 about The Guidance of Service for Believers of God, stipulated that the scope of service that given from local government it's comprise administrations of believers organizations and other service to making capacity building of organization such as meeting hall and burial service is could not be realized properly. The government service still facing resistance of s ociety that obs truct to implementation because they considered the believers of God as deviant peoples.

PBM of Mendagri and Mendikbudpar Number 43/41 Year 2009 about The Guidance of Service for Believers of God is stipulated that LocalGovernment supposed to provide public burial place when believers of God faced rejection from public burial place by majority religion. But in fact the regulation of that service for believers of God not much known by local government so it impact when burial of the believers of God in many region had rejection, finally they provide itself without support from the local government.

In many cases of rejection the burial of the believers of God like in Brebes and Indramayu, official of local government tend to pushing believers in order not to buried their family in public burial place. Even that Indonesian Ulema Councils (MUI) in Indramayu is sued a fatwa No. No.01/MUDESII/MUI/11/2012 that stated the tenet of Sapta Darma is categorized deviant tenet and pervert. This fatwa exhaled to chief of Sub-dis trict of Losarang, Bakorpakemand office of civil affairs of Indramayu. Related with the fatwa this institutions had no objection or regret about the act of MUI of Indramayu.

That conditions show us how weakness and powerles s of local government when they facing majority religion interest. Even if abuse and realize it ' $s$ dis criminate believers because their faith different with the other religion (like Is lam as majority religion), they cannot doing anything and tend to agreed. It's also show us that local government cannot implemented PBM of Mendagri and Mendikbudpar Number 43/41 Year 2009 about The Guidance of Service for Believers of God and on the contrary they active to support majority religion with neglecting the rights of believers of God to buried in public burial place. Even though explanation of the regulation was very clear giving about government responsibility against believers of God through their rights in burial place. When there were some rejections from local people, the government should have to facilitate burial ground/areathat can be using for burial of believers of God. The functions of facilitate burial ground forbelievers is supposed to be implemented by local government. Beside that the power of local government is very enable to organize and to enforce that the public burial place is public area which is no discrimination based on religion for using it, so every bodies that lay down in public burial place had same rights for proper buried.

When were any rejection from the society about the burial of believers of God in public burial place, the state should not obey and absence for active intervention. The state as a government through their official should to putting down as a judge and all at once become protector for citizen. The governmentmust take action to make better condition with provide special treatment to increasing fulfillment of believers of God human rights.

Is aiah Berlin argued, there are two kind of freedom, firstly negative freedom and the second is positive freedom. In terminology of negative freedom, is defined as freedom from. Mean while positive freedomis defined as freedomto take advantageous actions, to take part for capacity 
building and development itself, and to having role on good governance. The concept of these freedom is become positive comprehend. The freedomno longer had meaning with freedom from but furthermore is became freedomto.[10]. For now, this second concept it's supposed to do by the government, to take action freely without fear frommajority interest to firmout position of believers as same as religion.

The government should have political will to encountered common interest that discriminate believers of God. Government must examine the common interest which is consist majority interest frommajority religion had suppressintention to avoid of the growth of believers of God tenets. Researcher agreed with Rousseau though when where putting down freedom related with individual rights and common interest, it should have some restriction. Every right should have some restriction, because unlimited rights could impact exploitation and un freedom itself. Only with some restriction for the rights will created consistency with people sovereignty. When individual rights consist of some restriction, so should it for common interest. Common interest in society will happened on sovereign society. Inside that sovereign society just form possibly when there were condition which guarantee of equality of rights for the citizen to develop and realization itself.

However the condition of Indonesia society freedomrelated with the rights for religious and conscience freedomis still layering. The top of rank frompopulation of religionist is very powerful and could influence any living scope of religious life. So when public order is disrupted by believers of God that claim their rights, the government just gave artificial regulation for burial place for believers of God.

There is paradox in the regulation of the scope of service for believers of God related their burial place. In PBM of Mendagri and Mendikbudpar Number 43/41 Year 2009 about The Guidance of Service for Believers of God, it seem the government act like to served and protected believers of God rights, but in fact the government had no power to contrary with rejection of society. This rule just made for lip service because it seem giving protection but realize it cannot implementation to solve the problem. The burialservice for believers of God that stipulated provide by local government but the fact must be done by believers of God to provide itself with considered burial activity is individual interest. This fact is show us there is obscurity of law which impact unjust and neglected of believers of God rights.

The principle of human rights and citizen rights in UUD 1945 is manifestation of the vision of the state in Pancasila as fundament of the concept the state based on the law as called welfare state (verzorgingstaat) which consist of material and spiritual prosperity.[11] But reflected this case, it's became ironic in democratic welfare state, cause the public service for implementing justice and prosperous society is not happened. Even individualis $m$ had seem clearly when related with believers of God burial rights, it clear contrary with the concept of welfare state in Indonesia. For making solution, the government is ought to be taking action to created equality before the law within religionist and believers of God in every citizen and human rights. This action necessarily to provide service for fulfillment of the basic rights (human rights and citizen rights) including burial rights for believers of God in neutral public burial place. PBM of Mendagri and Mendikbudpar Number 43/41 Year 2009 about The Guidance of Service for Believers of God has no legality to giving service for believers of God, because until now there is not such higher regulation like Law that regulated the freedom of conscience and faith. It's urgent to making law that guaranteed every kind of regulation that ruled the spiritual living including burial process for believers of God.

Related with PBM of Mendagri and Mendikbudpar Number 43/41 Year 2009 about The Guidance of Service for Believers of God, it's should implementing with clear guidance related local government responsibility through providing public area for neutral public burial 
place for believers of God. It's need support with changing structure and substantive legal content that guaranteed implementation to belief and manifestation of their conscience. When the government take decisively action, so it's certainly the fulfillment of welfare state concept within this context is burial rights of believer in God in public burial place can be make it happened.

\section{Conclusion}

The rule of proper burial place for believers of God in public burial place is one of crucial point to do. The government should revoke rule of public burial place that only recognized for 5 religions and change it into government regulations to implementing constitutional court including burial place for believers of God. Only with intervention of law making from government to public burialplace regulation for believers of God without dis crimination it can make the concept of welfare state in Indonesia really happened.

The government should take decisive action to defend the burial rights of believers in public burial place when they facing rejection from society. The protection of human rights of believers of God it's should be done like protecting human rights like the other religion and faith. For implementation of PBM of Mendagri and Mendikbudpar Number 43/41 Year 2009 about The Guidance of Service for Believers of God need to eras ing the word "if they rejected (the burial in public burial place), the believer should provide itself", and change with "the government will take action to provide public burial place in such a state land which is pointed". It's have meaning when the government want to respect and protect the human rights for all citizen, so it's should providing seriously as a kind of governmentres ponsibility.

Furthermore, the government should take active as sistance to local government to ensure that regulation could beimplementation without any rejection and or discrimination against believers of God. Only with equal condition that given from the government it can make equal result for fulfillment of welfare state concept in Indonesia based on Pancasila principles.

\section{References}

[1] Nazar Nurdin, Gloomy Portrait Of The Death of Believers of God of Sapta Darma, Annual International Conference on Islamic Studies in ST AIN Samarinda, with tittle Responding the Chalenges of Multicultural Societies: The Contribution of Indonesian Islamic Studies, Samarinda, 21-24 November 2014

[2] Government Regulation (PP) No.9 year 1987 about Land Use Provision for Public Burial Place

[3] eLSA, Investigating Report of Religion and Social Studies, Report on Religious Freedom, not published, Semarang, 2014,1.

[4] Komnas Perempuan, Investigating Report for discriminations and violence against women in the context of Freedom of Religions and Conscience for Believers of God and Ritual Tradition, Komnas Perempuan, Jakarta, 2016, 36-72

[5] A.V Dicey, Introduction to the Study of the Law of the Constitution, ed. Roger E. Michener, Indianapolis: Liberty Fund, 1982, 153.

[6] Hotma Sibuea, Principles of State Law, Public Policy and The Prinsiples of Good Governance, Erlangga, Jakarta, 2010, 40

[7] Friedman, Legal Theory and Philosophi of Law : Philosophi Idealism and the Problem of Justice, Jakarta: Rajawali Press Publishing $1^{\text {st }}$ edition, 1991, 65

[8] Jimly Asshiddiqie, Constitution and Constitutionalism, General Secretary and Registrar of Constitutional Court of Republic Indonesia, Jakarta, 2006, 55 
[9] Ali, Ahmad, Reveal of Legal Theory and Theory of Justice (Judicialprudence): Including Law Interpretation, Prenadamedia Jakarta, 2009,.235

[10] Fitriciada, Aidul, Constitutions Interpretation (Tafsir Konstitusi), Jagat Abjad, Surakarta, 2010 , 112

[11] Azhari, Indonesian Rule of Law, Juridical Analysis About that Content, UI Press, Jakarta, 1995, 145. 